\title{
Thomas Maillet (?), Les Proverbez d'Alain
}

\section{Maria Colombo Timelli}

\section{OpenEdition}

\section{Journals}

Édition électronique

URL : http://journals.openedition.org/studifrancesi/9118

DOI : ERREUR PDO dans /localdata/www-bin/Core/Core/Db/Db.class.php L.34 : SQLSTATE[HY000]

[2006] MySQL server has gone away

ISSN : 2421-5856

\section{Éditeur}

Rosenberg \& Sellier

\section{Édition imprimée}

Date de publication : 1 juin 2008

Pagination : 161

ISSN : 0039-2944

\section{Référence électronique}

Maria Colombo Timelli, « Thomas Maillet (?), Les Proverbez d'Alain », Studi Francesi [En ligne], 154 (LII I

I) | 2008, mis en ligne le 30 novembre 2015, consulté le 07 janvier 2021. URL : http://

journals.openedition.org/studifrancesi/9118; DOI : https://doi.org/10.4000/studifrancesi.9118

Ce document a été généré automatiquement le 7 janvier 2021.

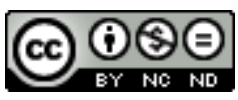

Studi Francesi è distribuita con Licenza Creative Commons Attribuzione - Non commerciale - Non opere derivate 4.0 Internazionale. 


\title{
Thomas Maillet (?), Les Proverbez d'Alain
}

\author{
Maria Colombo Timelli
}

\section{RÉFÉRENCE}

THOMAS MAILLET (?), Les Proverbez d'Alain, Édités par Tony HUNT, Paris, Champion, 2007

(«Classiques Français du Moyen Âge», 151), pp. 135.

1 Le manuscrit BnF fr. 12478 est l'un des nombreux recueils qui ont diffusé, tout au long du Moyen Âge, le florilège connu sous l'intitulé Auctores octo morales, rendu célèbre par la condamnation sans appel prononcée par Rabelais (Gargantua, XIII). Dans la description du codex, qui néglige un peu les aspects matériels, Tony Hunt donne non seulement la liste des pièces (version partielle des Remedia amoris, Ars amatoria traduite par Jacques d'Amiens, Puissance d'amour, Téodolet, Proverbes d'Alain de Lille, deux Facet), mais il en transcrit des extraits parfois assez étendus, qu'il commente en les rapportant à l'ensemble de la tradition. Avant-dernière pièce du recueil, les Proverbez constituent une des trois traductions françaises du Liber parabolarum d'Alain de Lille, longue série de distiques d'allure sentencieuse et morale, pour un total de 650 vers: avec cette édition, Tony Hunt complète la série, après avoir publié lui-même la version la plus ancienne (paraphrase en prose anglo-normande, un seul ms. du XIII ${ }^{\mathrm{e}}$ siècle, cfr. «Le Moyen Âge», 87, 1981), et la plus récente (un incunable d'Antoine Vérard et une édition de Denis Janot, 1534-35: London, MHRA, 2006). Cette traduction, qui redouble presque l'original latin (1268 vers), est structurée comme celui-ci en six livres, à l'intérieur desquels les distiques sont associés en nombre croissant: 56 strophes de 2 vers (livre I), 26 de 4 (livre II), 17 de 6 (livre III), 13 de 8 (livre IV), 10 de 10 (livre V), 10 de 12 (livre VI). L'auteur, qui déclare ses intentions didactiques dans le «Prologue», semble devoir être identifié avec Thomas Maillet, comme le suggèrent les tout derniers vers, personnage par ailleurs totalement inconnu, alors que l'œuvre peut être datée de la fin du XIV ${ }^{\mathrm{e}}$ siècle. Tony Hunt consacre un chapitre à l'analyse linguistique: des picardismes certains, ainsi que quelques lemmes très caractérisés en raison de leur rareté, 
ressortissent sur une scripta littéraire somme toute assez neutre. Le texte est édité avec soin; il est accompagné de notes qui font aussi service d'apparat critique; suit un glossaire sobre mais complet. En appendice, le texte latin d'Alain de Lille, dont la source n'est pas indiquée. 